\title{
EVALUATION OF FINANCIAL PERFORMANCE ACCORDING TO FIRM SCALE: CASE OF MANUFACTURING SECTOR
}

\author{
DOI: 10.17261/Pressacademia.2018.857 \\ PAP- V.7-2018(10)-p.62-66
}

\section{Kemal Eyuboglu ${ }^{1}$, Yasar Bayraktar ${ }^{2}$}

${ }^{1}$ Karadeniz Technical University, Department of Business Administration, Trabzon, Turkey. keyuboglu@ktu.edu.tr, ORCID: 0000-0002-2108-9732

${ }^{2}$ Karadeniz Technical University, Department of Business Administration, Trabzon, Turkey. yasarbayraktar@ktu.edu.tr, ORCID: 0000-0002-6974-5292

To cite this document

Eyuboglu, K., Bayraktar, Y. (2018). Evaluation of financial performance according to firm scale: case of manufacturing sector. PressAcademia Procedia (PAP), V.7, p.62-66.

Permemant link to this document: http://doi.org/10.17261/Pressacademia.2018.857

Copyright: Published by PressAcademia and limited licenced re-use rights only.

\section{ABSTRACT}

Purpose- Companies are classified as large, medium and small enterprises according to their scale. The purpose of the study discussed in this context is to compare the financial performance of the small, medium and large-scaled companies in manufacturing sector which has an important place in Turkey's economy, by addressing the 2014-2016 period.

Methodology- In the study, 19 financial ratios related to liquidity, financial structure, activity and profitability were used. Firstly weights of criteria were determined by using AHP method and then companies were ranked according to scale by TOPSIS method.

Findings- As a result of the analyzes, it was determined that small and medium scaled firms, although they have a significant volume in numerical terms, perform relatively poorly in terms of financial performance compared to large scale firms.

Conclusion- It is thought that the main cause of this situation for small and medium scaled companies is not being able to benefit from scale economies and capital shortage.

Keywords: Firm scale, AHP, TOPSIS, financial performance, manufacturing sector, Turkey. JEL Codes: C02, C44, M21

\section{INTRODUCTION}

Companies are classified as large, medium and small enterprises according to their scale. These scales can provide some advantages to the firms. As a company grows in scale, the advantages of specialization in terms of labor and mechanization are also increasing in production process. The benefiting from scale economy in large-scale firms increases the firm's profit. Because, in large-scale companies, it is possible to obtain some inputs at a cheaper price due to the possibility of purchasing in high quantities. Thus, other conditions remaining the same, it is reduced production costs.

In the case of small-scale firms, the ability to focus on products and markets, the ability to specialize, the flexibility to enter markets with limited demand, the ability to react quickly to changes in market conditions and consumer preferences, and the ability to use qualified technology can be an advantage (Güngör, 2017: 22). However, in addition to these advantages, Gupta (1969) studied on the influence of firm scale on financial structure. It is found that small-scale firms have difficulties in finding funds because their inventory and cash turnover rates are high and average collections periods are low. In addition, there is a negative relationship between borrowing rate and firm scale. The reason for this negative relationship is that the financial risk of small firms is high. It is also found that the debt of small firms is mainly composed of short-term debt (Ata \& Ag, 2010: 50).

\section{LITERATURE REVIEW}

In the literature, multi-criteria decision-making method is used to analyze the financial performance of businesses in different sectors. Meydan et al. (2016) assessed the financial performance of food companies traded in BIST for 2012. In this context, the financial ratios (liquidity, activity, financial structure and profitability ratios) of enterprises were taken as group and whole separately. The financial performances of the businesses were analyzed by using Gray Relational Analysis method in both cases. As a result, Ülker Gıda ranked first in overall financial performance and Penguin Food ranked last in ranking. Orçun and Eren (2017) evaluated the financial performances of technology companies traded in BIST covering the period 2010-2015 by using the TOPSIS method. As a result of the analysis, it was determined that the most successful companies in terms of performance are ASELS, LINK, ARMDA, LINK, INDES and DGATE respectively. Şit et al. (2017) analyzed the financial performances of BIST Main Metal Index companies during the 2011-2015 period. In the study, 
frequently used ratios of liquidity, activity, financial structure, profitability and stock market performance ratios were determined and compared with TOPSIS management. As a result of the study, it was determined that financial performances of the companies operating in the sector vary from year to year.

\section{DATA AND METHODOLOGY}

The comparison of financial performances according to the scales of the companies gathered from financial ratios included in the Sectoral Balance Sheet Statistics published by The Central Bank of The Republic of Turkey (CBRT). In the determination of the scale ranges, "net sales" adopted by CBRT by BACH and "asset size" criteria used by European Union are taken as basis. Under the net sales criteria; companies with net sales of less than 10 Million Euros in 2016 are on the small scale, those between 10 Million Euros and 50 Million Euros are on the medium scale and those over 50 Million Euros are on the big scale. In sectors analyzed according to asset size criteria; Companies with a total of less than 10 Million Euros in 2016 are classified as small-scale, firms with a size between 10 Million Euros and 43 Million Euros are classified as medium-scale and those with a size greater than 43 Million Euros are classified as large-scale. In the CBRT study, 1467 small-scale, 1082 medium-scale and 508 large-scale firms were taken into account. In the study, 19 financial ratios related to liquidity, financial structure, activity and profitability were used. Because it requires a multi-criteria framework for performance evaluation, MCDM methods were utilized in the study. AHP is used to determine the weights of the criteria and TOPSIS methods were used in performance ranking.

\section{FINDINGS}

In this part of the study, the financial performance of the manufacturing sector is calculated and interpreted according to firm scale for 2014-2016 period.

\subsection{Determination of Weights of Financial Ratios}

The weight of each criterion is determined by AHP method in comparing financial performances according to firm scale. Here, we have been interviewed by expert academics and sector managers when creating pair-wise comparison matrices. Then the answers are analyzed in Super Decision program and the importance ratings of each criterion were determined. The consistency rate (CR) was calculated as 0,06 . The weights of the financial ratios are shown in Table 1.

Table 1: Weights of Financial Ratios

\begin{tabular}{|c|c|c|c|}
\hline Basic Ratios & Weights & Sub-Ratios & Weights \\
\hline \multirow{4}{*}{ Liquidity Ratios } & \multirow{4}{*}{0.261} & L1 Current Ratio & 0,088 \\
\hline & & L2 Quick Ratio & 0,076 \\
\hline & & L3 Cash Ratio & 0,059 \\
\hline & & L4 Inventory Dependency Ratio & 0,038 \\
\hline \multirow{4}{*}{ Financial Structure Ratios } & \multirow{4}{*}{0.175} & F1 Total Debt/Assets & 0,032 \\
\hline & & F2 Equity/Assets & 0,043 \\
\hline & & F3 Short Term Liabilities/Total Liabilities & 0,058 \\
\hline & & F4 Net Tangible Assets/Equity & 0,042 \\
\hline \multirow{5}{*}{ Activitiy Ratios } & \multirow{5}{*}{0.247} & A1 Inventory Turnover & 0,058 \\
\hline & & A2 Receivable Turnover & 0,041 \\
\hline & & A3 Net Working Capital Turnover & 0,049 \\
\hline & & A4 Equity Turnover & 0,044 \\
\hline & & A5 Asset Turnover & 0,055 \\
\hline \multirow{6}{*}{ Profitability Ratios } & \multirow{6}{*}{0.317} & P1 Net Profit/Equity & 0,066 \\
\hline & & P2 EBIT/Assets & 0,039 \\
\hline & & P3 Net Profit/Assets & 0,042 \\
\hline & & P4 Operating Profit/Net Sales & 0,046 \\
\hline & & P5 Gross Profit /Net Sales & 0,055 \\
\hline & & P6 Net Profit / Net Sales & 0,069 \\
\hline
\end{tabular}

\subsection{Evaluation of Financial Performance with TOPSIS Method}

As shown in Table 2, the top line of the decision matrix contains weight values indicating the importance of each criterion. Weight values are obtained by evaluating questionnaires containing pair-wise comparisons through AHP approach. Three decision points (firm scale) and 19 evaluation criteria (financial ratios) are used in the study. In the first stage $(3 \times 19)$ dimensional decision matrices are created in the application of the TOPSIS method. 
Table 2: Decision Matrices

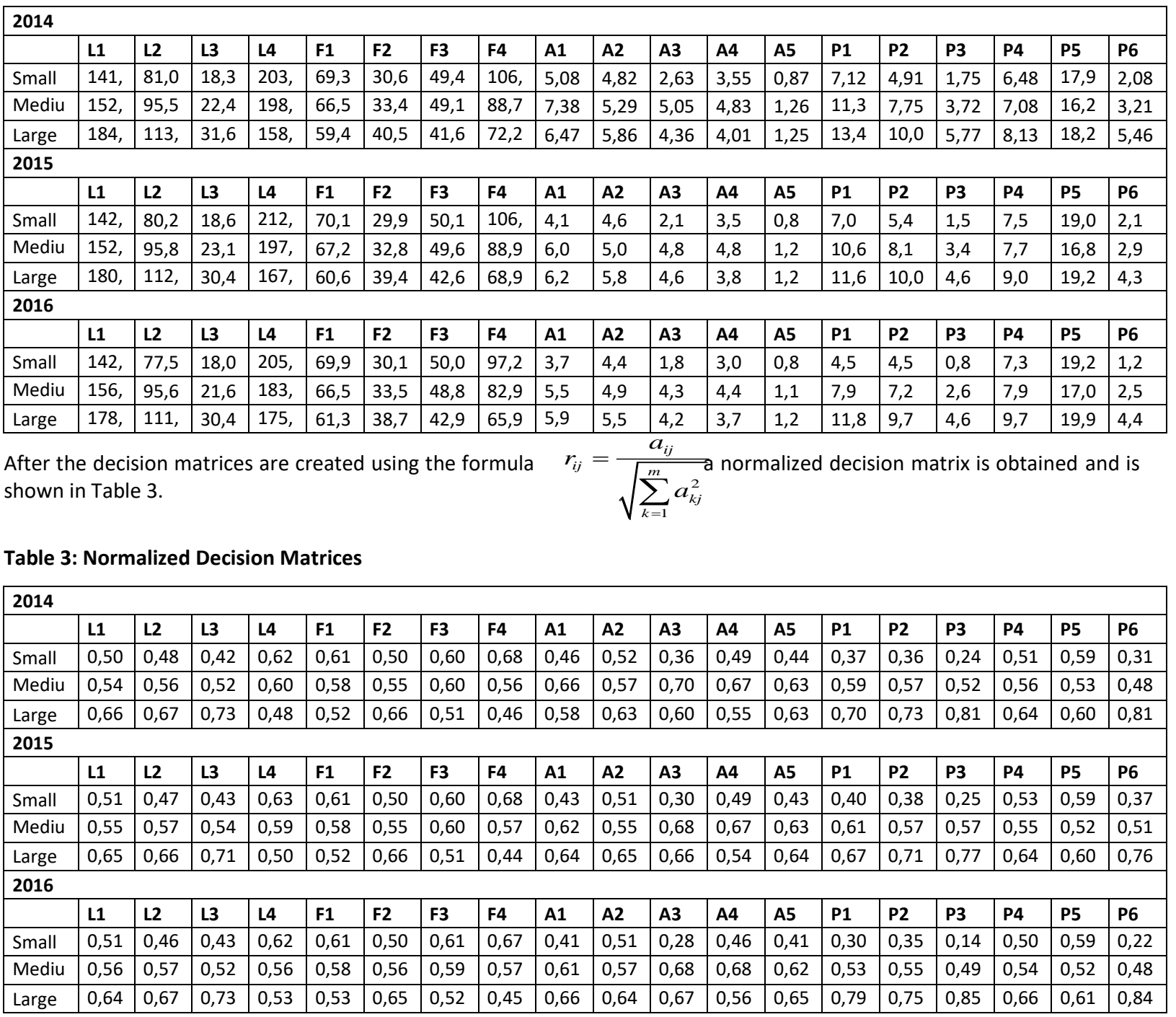

The weighted standard decision matrix is obtained by multiplying the normalized values by weights (Vij = wij x Rij) and is shown in Table 4 .

Table 4: Weighted Standard Decision Matrices

\begin{tabular}{|c|c|c|c|c|c|c|c|c|c|c|c|c|c|c|c|c|c|c|c|}
\hline \multicolumn{20}{|l|}{2014} \\
\hline & L1 & L2 & L3 & \begin{tabular}{|l|} 
L4 \\
\end{tabular} & F1 & F2 & F3 & F4 & A1 & A2 & A3 & A4 & A5 & P1 & P2 & P3 & P4 & P5 & \begin{tabular}{|l|} 
P6 \\
\end{tabular} \\
\hline Small & 0,04 & 0,03 & 0,02 & 0,02 & 0,02 & 0,02 & 0,03 & 0,02 & 0,02 & 0,02 & 0,01 & 0,02 & 0,02 & 0,02 & 0,01 & 0,01 & 0,02 & 0,03 & 0,02 \\
\hline Mediu & 0,04 & 0,04 & 0,03 & 0,02 & 0,01 & 0,02 & 0,03 & 0,02 & 0,03 & 0,02 & 0,03 & 0,02 & 0,03 & 0,03 & 0,02 & 0,02 & 0,02 & 0,02 & \begin{tabular}{|l|}
0,03 \\
\end{tabular} \\
\hline Large & 0,05 & 0,05 & 0,04 & 0,01 & 0,01 & 0,02 & 0,03 & 0,01 & 0,03 & 0,02 & 0,03 & 0,02 & 0,03 & 0,04 & 0,02 & 0,03 & 0,03 & 0,03 & 0,05 \\
\hline \multicolumn{20}{|l|}{2015} \\
\hline & L1 & L2 & L3 & L4 & F1 & F2 & F3 & F4 & A1 & A2 & A3 & A4 & A5 & P1 & \begin{tabular}{|l|} 
P2 \\
\end{tabular} & P3 & P4 & P5 & P6 \\
\hline Small & 0,04 & 0,03 & 0,02 & 0,02 & 0,02 & 0,02 & 0,03 & 0,02 & 0,02 & 0,02 & 0,01 & 0,02 & 0,02 & 0,02 & 0,01 & 0,01 & 0,02 & 0,03 & 0,02 \\
\hline Mediu & 0,04 & 0,04 & 0,03 & 0,02 & 0,01 & 0,02 & 0,03 & 0,02 & 0,03 & 0,02 & 0,03 & 0,03 & 0,03 & 0,04 & 0,02 & 0,02 & 0,02 & 0,02 & \begin{tabular}{|l|}
0,03 \\
\end{tabular} \\
\hline Large & 0,05 & 0,05 & 0,04 & 0,01 & 0,01 & 0,02 & 0,03 & 0,01 & 0,03 & 0,02 & 0,03 & 0,02 & 0,03 & 0,04 & 0,02 & 0,03 & 0,03 & 0,03 & \begin{tabular}{|l|}
0,05 \\
\end{tabular} \\
\hline \multicolumn{20}{|l|}{2016} \\
\hline & L1 & L2 & L3 & L4 & F1 & F2 & F3 & F4 & A1 & A2 & A3 & A4 & A5 & P1 & P2 & P3 & P4 & P5 & P6 \\
\hline Small & 0,04 & 0,03 & 0,02 & 0,02 & 0,02 & 0,02 & 0,03 & 0,02 & 0,02 & 0,02 & 0,01 & 0,02 & 0,02 & 0,02 & \begin{tabular}{|l|}
0,01 \\
\end{tabular} & 0,00 & 0,02 & 0,03 & \begin{tabular}{|l|}
0,01 \\
\end{tabular} \\
\hline Mediu & 0,05 & 0,04 & 0,03 & 0,02 & 0,01 & 0,02 & 0,03 & 0,02 & 0,03 & 0,02 & 0,03 & 0,03 & 0,03 & 0,03 & 0,02 & 0,02 & 0,02 & 0,02 & 0,03 \\
\hline Large & 0,05 & 0,05 & 0,04 & 0,02 & 0,01 & 0,02 & 0,03 & 0,01 & 0,03 & 0,02 & 0,03 & 0,02 & 0,03 & 0,05 & 0,02 & 0,03 & 0,03 & 0,03 & 0,05 \\
\hline
\end{tabular}


Then ideal $\left(A^{+}\right)$and negative ideal $\left(A^{-}\right)$solutions were created. For the $A^{+}$set, the largest value in each column of the $V$ matrix is chosen as the smallest value in each column of the $V$ matrix for $A^{-}$set. The sets are shown in Table 5 for the purposes of the criteria.

\section{Table 5: Ideal $\left(\mathrm{A}^{+}\right)$and Negative Ideal $\left(\mathrm{A}^{-}\right)$Solutions}

\begin{tabular}{|l|l|l|l|l|l|l|l|l|l|l|l|l|l|l|l|l|l|l|l|}
\hline $\mathbf{2 0 1 4}$ \\
\hline $\mathbf{A}^{*}$ & 0,05 & 0,05 & 0,04 & 0,01 & 0,01 & 0,02 & 0,03 & 0,01 & 0,03 & 0,02 & 0,03 & 0,02 & 0,03 & 0,04 & 0,02 & 0,03 & 0,03 & 0,03 & 0,05 \\
\hline $\mathbf{A}^{-}$ & 0,04 & 0,03 & 0,02 & 0,02 & 0,02 & 0,02 & 0,03 & 0,02 & 0,02 & 0,02 & 0,01 & 0,02 & 0,02 & 0,02 & 0,01 & 0,01 & 0,02 & 0,02 & 0,02 \\
\hline $\mathbf{2 0 1 5}$ \\
\hline $\mathbf{2}$
\end{tabular}

Distances $\left(\mathrm{Si}^{+}\right)$from the positive-ideal solution, the distances from the negative-ideal solution (Si), the performance scores and the rankings of the manufacturing sector firm scales by years are presented in Table 6.

Table 6: Performance Scores and Rankings of Scales by Years

\begin{tabular}{|c|c|c|c|c|}
\hline \multicolumn{5}{|l|}{2014} \\
\hline Scale & $\mathbf{S}^{*}$ & $\mathrm{~S}^{-}$ & (C) Score & Ranking \\
\hline Small & 0,064 & 0,003 & 0,052 & 3 \\
\hline Medium & 0,035 & 0,036 & 1,045 & 2 \\
\hline Large & 0,008 & 0,062 & 7,424 & 1 \\
\hline \multicolumn{5}{|l|}{2015} \\
\hline Scale & S* & $\mathrm{s}^{-}$ & (C) Score & Ranking \\
\hline Small & 0,057 & 0,004 & 0,072 & 3 \\
\hline Medium & 0,028 & 0,036 & 1,319 & 2 \\
\hline Large & 0,006 & 0,056 & 9,318 & 1 \\
\hline \multicolumn{5}{|l|}{2016} \\
\hline Scale & $\mathrm{S}^{*}$ & $\mathrm{~S}^{-}$ & (C) Score & Ranking \\
\hline Small & 0,076 & 0,039 & 0,553 & 3 \\
\hline Medium & 0,040 & 0,012 & 0,805 & 2 \\
\hline Large & 0,005 & 0,045 & 8,806 & 1 \\
\hline
\end{tabular}

Findings indicate that large scale firms show better financial performance compared to medium and small scale firms during the related period. This situation is thought to be caused by scale economies.

Scale economies are defined as the decrease in average cost while the production capacity measured by unit output is increasing. In other words, they are reductions in unit costs resulting from the increased transaction scale.

As a matter of fact, the larger the scale of a company's facility, the greater the bargaining power of the company in the international market, and therefore the firm is able to obtain the production factors it buys at lower prices (Güngör, 2017: 23). This situation also contributes positively to the profitability ratios. According to this, while medium and large scaled companies reached the highest performance values in 2015, it is seen that the small sized companies reached the highest performance value in 2016 . This is thought to be the contribution of incentives and credit guarantee funds that the government has explained.

\section{CONCLUSION}

Increasing competition conditions are pushing companies. One of the industries holds an important place in Turkey's economy is the manufacturing sector. In this study, the financial performances of small, medium and large scale companies in manufacturing sector were compared over the period 2014-2016.

In the study, liquidity, financial structure, activity and profitability ratios are used. Firstly, the weights of the ratios were determined by using AHP method and then the performance scores of the scales were calculated and sorted by TOPSIS method. As a result of the analysis, it was determined that SMEs perform considerably poorly in terms of financial performance compared to large scale firms even though they are in significant numbers. The most important problem of the small and medium-scaled firms in Turkey is the lack of sufficient working capital. This increases costs, making it difficult to fulfill obligations and to work at full capacity. Therefore, the findings are consisted with expected results. In this respect, SMEs' access to finance at low cost will be beneficial in terms of enabling them to sustain their activities. 


\section{REFERENCES}

Ata, H. A., Ağ, A. G. Y. (2010). Firma karakteristiğinin sermaye yapısı üzerindeki etkisinin analizi. Ekonometri ve İstatistik e-Dergisi, (11), 4560

Gupta, M. (1969). The effect of size, growth, and industry on the financial structure of manufacturing companies. Journal of Finance, 24(3), 517-529.

Güngör, G. A. (2017). Türkiye imalat sanayinde firma ölçeği değişmeleri ve ihracat performansı ilişkisi. International Journal of Academic Value Studies, 3(13), 21-39.

Meydan, C., Yıldırım, B. F., Senger, Ö. (2016). BiST’te işlem gören gıda işletmelerinin finansal performanslarının gri ilişkisel analiz yöntemi kullanılarak değerlendirilmesi. Muhasebe ve Finansman Dergisi, (69), 147-167.

Orçun, Ç., Eren, B. S. (2017). TOPSIS yöntemi ile finansal performans değerlendirmesi: XUTEK üzerinde bir uygulama. Muhasebe ve Finansman Dergisi, (75), 139-154.

Şit, A, Ekşi, I. H., Hacıevliyagil, N. (2017). BIST’te ana metal sanayi endeksinde faaliyet gösteren işletmelerin finansal performans ölçümü: 2011-2015 dönemi. Süleyman Demirel Üniversitesi Vizyoner Dergisi, 8(17), 83-91.

Türkiye Cumhuriyet Merkez Bankası, http://www3.tcmb.gov.tr/sektor/2017/menu.php, 24.02.2018. 